\title{
Cyanide Poisoning in Cattle
}

\author{
Kutay Yildiz, Banu Dokuzeylul, Remzi Gonul and M Erman OR* \\ Department of Internal Medicine, Istanbul University, Turkey
}

Submission: March 13, 2017; Published: March 23, 2017

*Corresponding author: M Erman OR, Department of Internal Medicine, Istanbul University, Turkey, Tel: +905326370989;

Email: bdokuzeylul@gmail.com

\begin{abstract}
Cyanide is one of the most vigorous toxins in the nature and it can affect all animals including cattle. Ruminants can be easily affected by this toxin because of their feeding style.More than 2000 plant species includes cyanogenic glycosides and these glycosides are converted to hydrogen cyanide by hydrolisation in the body. After the hydrolisation, hydrogen cyanide merges with methemoglobin and this complex inhibits the oxidative phosphorylation. As a result of these processes, affected animals may die. The toxin can affect animals rapidly. In clinical examination cherry-red colored mucous membranes and in the necropsy early formation of death attendance are the cardinal symptoms of cyanide poisoning. If the treatment performed rapidly, toxin can be neutralised but in the most cases the animals die due to rapidly acting nature of the toxin. It is important to pay attention to prevention from this toxication
\end{abstract}

The aim of this review is to examine the cyanide poisoning, its diagnosis, treatment and prevention.

Keywords: Cyanide; Cattle; Toxication; Hydrogen cyanide

\section{Introduction}

Cyanide is one of the most rapidly acting toxins which affects the cattle population. It is also known as prussic and hydrocyanic acid. Hydrogen cyanid (HCN) was isolated from blue dye (Prussian blue) for the first time and because of its acidic nature it's also known as "prussic acid" [1,2]. Hydrocyanic acid is a colorless voletile gas with bitter almond odor. More than 2000 plant species includes cyanogenic glycosides. Tare and sorghumare the most common resource of the prussic acid and these plants are the reasons of toxicity in most cases [2-4]. However the plants are the most important source of cyanide toxicity in animals, cyanide is used in manure, textile, paint industry, pesticides and insecticites.Cherry, peach, plum and bitter almond also includes cyanide. Cherry kernels include about $170 \mathrm{mg}$ cyanoglycosid for per $100 \mathrm{~g}$ and bitter almond pulps include about $250 \mathrm{mg}$ for per $100 \mathrm{~g}$. Exposure to excessive cyanide can be fatal $[1,3,5,6]$.

The aim of this review is to examine the cyanide poisoning, its diagnosis, treatment and prevention.

\section{Etiopathology}

Cyanogenic plants contain cyanide as cyanogenic glycosides. Normally these glycosides are not toxic but when hydrolyzed, they become toxic to both animals and humans [1,3,7]. It is reported that if the plant is freezed, chopped or chewed, damaged plant cells can release enzymes in their vacuoles, this enzymes and cyanoglycosides may contact with each other and produce cyanure [1-4]. Cattle has bacterias that can produce the same enzymes in their rumen microflora and can convert the cyanogenic glycosides to cyanure gas [7,9]. Amygdalin, Prunacin, Linamaryn, Lotaustralyn, Dhurryn, Taxiphylyn, Vicianyn, Proteacyn ve Gynocardyn have been detected as most common glycosides in cyanogenic plants [3].

It is reported that some factors such as rapid ingestion, ruminal $\mathrm{pH}$ and microflora, ingestion of a large amount of cyanogenic plant, amount of cyanogenic glycoside or free HCN in ingested plant can increase the toxicity level. The risk of toxicity decreases with maturity of the plant, older plants and leaves contain less cyanogenic glycoside $[2,6,8]$. It is shown that some herbicides like 2,4-Dichlorophenoxyacetic acidcan increase the potential toxicity of plant after the application [2]. Excess of nitrogen and fewness of phosphorus in the soil can increase the toxicity of the plant as determined. High ruminal and abomasal $\mathrm{pH}$ increasethe severity of toxicity. However, if the $\mathrm{pH}$ is lower than 5.0, the enzymes that separate the glycosides from the cyano become denatured and toxicity does not occur $[1,2,6,7]$.

The lethal dose of HCN for cattle and sheep is about $2 \mathrm{mg} /$ $\mathrm{kg}$ of body weight $[1,2,6,7]$. The plants are considered as toxic if they contain over $200 \mathrm{ppm}$ of these glycosides.If the cyanide is taken to the body, it's rapidly absorbed and circulated, then it's merged with methemoglobin and forms cyanomethemoglobin. The circulating cyanide inactivates cytochrome oxidase 
enzyme by binding ferric $(\mathrm{Fe}+++)$ iron which is within this enzyme. Normally the cytochrome oxidase enzyme catalyzes the last step of oxidative phosphorylation. The enzyme-cyanide complex prevents this task from being performed. Because of that the enzyme can not combine with oxygen and electron transportation become inhibited. The patient can not use caloric oxygen and cellular respiration stops immediately. As a result of this process, death occurs due to histotoxic anoxia $[4,7]$.

\section{Clinical Signs}

Cyanure is one of the most vigorous toxins and can cause death in a short amount of time.The toxicity depends on amount of ingested cyanogenic structure and ingestive rate, affected cattles rapidly begin to show toxication symptoms [6,7]. Arnold \& Gaskill [2] described that toxication symptoms may occur in 5-15 minutes to a few hours, but usually patients do not survive 2 hours after consuming the lethal dose of cyanogenic structures. Dyspnea, labored breathing, restlessness, tremors, groaning, terminal clonic convulsions and opistothonus are the clinical signs in affected animals.Initially, when tissues can't use the oxygen, bright and cherry-red colored mucous membranes are noticed due to oxygen abundance in blood. When patient becomes hypoxic, mucous membranes become cyanotic $[2,6,7]$. When the intracellular cyanide concentration is less than $0.2 \mu \mathrm{g} /$ $\mathrm{ml}$, symptoms of poisoning do not occur. When the cyanide level is between 0.5 and $1 \mu \mathrm{g} / \mathrm{ml}$ hyperemia of the skin and tachycardia and between $1-2.5 \mu \mathrm{g} / \mathrm{ml}$ unconsciousness and excitement are seen. At the levels above, patients'll easily enter coma and die. Symptoms of poisoning occurs due to hypoxia [7].

In chronic poisonings, arthrogryposis can be observed in the calveswhich consume sorghum. Myelomalacia and urinary incontinence can be formed in some cases [4,7]. Patients may have incoordination, ataxia, head shaking and pawning in the posterior extremities. Decrease of productivity, difficulty on conceive and abortion can be also seen in such patients $[7,9]$.

\section{Diagnosis and Differential Diagnosis}

Cyanide analysis must be performed on suspected feeds and plants or cattle's rumen content for the diagnosis $[1,10]$. Sodium picrate test can be used for the cyanide detection in examples and commercial test kits are also available [2,7]. To perform an accurate analysis that leads to a correct diagnosis, collection of examples isvery important. The sample must remain fresh, if it is allowed to dry it end up with loss of prussic acid. It is reported that for collection and transmit, samples must be placed in a container that can be tightly sealed, samples must be frozen, and they must be transported in cold chain $[9,11]$.

In necropsy, early formation of death attendance can be observed. Blood can be seen in red colour because oxygen couldn't be kept and it's used by tissues $[2,12]$. Red and orange colour in the mouth and stomach can be observed. Bitter almond odor can be smeltin rumen and internal organs. Subendocardial and subpericardial hemorrhages occur in all cases $[8,11]$.
The challenges in recognizing acute cyanide poisoning can be originated from nonspecific early symptoms of toxicity such as dizziness, weakness, diaphoresis, hyperpnea and labored breathing. Patients including these symptoms can be misdiagnosed with nitrate poisoning, organophosphorus poisoning and sulphur poisoning [1-3]. An accurate diagnosis is essential because most of the clinical signs of prussic acid poisoning are similar to those poisonings $[7,13]$. There are some distinguishing characteristics to eliminate cyanide poisoning from other events. Prussic acid causes the animal's blood to turn a bright cherry red but in other events it won't be occurred. Providing sodium nitrite to animals suffering from nitrate poisoning rather than prussic acid poisoning could make these animals worse. Findings such as bitter almond odour and early formation of death attendance are characteristic to cyanide poisoning in the necropsy $[1,7,9]$.

\section{Treatment}

Treatment is often too late, and most cases result in death but some early noticed cases can be treated. However, sodium nitrate and sodium thiosulfate should be rapidly administered intravenously to affected cattles. Patient's rumen content should be removed and replaced with contents from an healthy animal $[2,4,9,13]$. This procedure should be repeated immediately to ensure complete removal of cyanogenetic material. Sodium nitrite and sodium thiosulphate are the specific antidotes for cyanide poisoning $[8,13]$. $20 \%$ of sodium nitrate and $20 \%$ of sodium thiosulphate mixture can be applied intravenously to animals [2]. After the treatment the respiratory rate become slower and the cattle seemed to be more relaxed. Patients must be placed in a position of sternal recumbency and an attempt must be doneto rise immediately $[1,9,14]$.

\section{Prevention}

Sorghum and sudangrasses should not be grazed when they are in an immature state. They must be allowed these forages to attain a height of 15 to 18 inches before grazing [11]. New varieties of sudangrass and sorghum with lower prussic acid content should be considered when selecting seed. The animals access to the wild cherry leaves must be interrupted [2]. Plants must not be grazed during drought periods when growth is severely reduced or the plant is wilted or twisted. Animals must have been provided sufficient feed, like hay, so they will not be hungry when they enter fresh pastures. This will reduce the amount of prussic acid consumed and allow more time for the animal to detoxify low levels of HCN. If high cyanide is suspected at the forages, cattles must not have been fed as green chop $[2,11]$.

\section{Conclusion}

Cyanide poisoning is one of the most important poisonings in animals. Especially cattle's pica ability, it became more dangerous. In this review it's aimed to pay attention to cyanide poisoning. 


\section{References}

1. (1970) Hydrogen Cyanide. Am Industrial Hyg Ass J 116-119.

2. Clarke ML, Harvey DG, Humphrey DJ (1981) Veterinary Toxicology. (2 edn), ELBS and Baillaire, Tindall, pp. 175-178

3. Gracia R, Shepherd G (2004) Cyanide poisoning and its treatment Pharmacotherapy 24: 1358-1365

4. Akgül G, Mecitoğlu Z, Şentürk S (2013) Sığırlarda respiratorik distrese ve asfeksiye yol açan önemli zehirlenmeler. Uludağ Üniv. J Fac Vet Med 32(1): 47-52.

5. Pirinçci I, Tanyıldızı S (1994) Yemlerdeki HCN düzeylerinin belirlenmesi. Vet Bil Derg 10(1-2): 84-89.

6. Vetter J (2000) Plant cyanogenic glycosides. Toxicon 38(1): 11-36.

7. Gurnsey MP, Janos WT, Merrall M (1977) Cyanide poisoning in cattle: two unusual cases. N Z Vet J 25(5): 128-130.
8. Carlson MP, Anderson B (2013) Cyanide poisoning.

9. Arnold M, Gaskill C (2014) Cyanide poisoning in ruminants. Agliculture and Natural Resources Publications, p. 168

10. Morocco AP (2005) Cyanides. Crit Care Clin 21(4): 691-705.

11. Nobrega JR, Escariao da J, Franklin RC, Rosary MT (2006) Poisoning by Sorghum halepense (Poaceae) in cattle in the Brezilian semiraid. Resq Vet Bra 26(4): 201-204.

12. Harshad PB, Shailesh NK, Chinag MM (2012) Treatment of cyanide poisoning in crossbred cows: a profile of drug synergism. IRJP 3(10): 169-170.

13. Borron SW (2006) Recognition and treatment of acute cyanide poisoning. J Emerg Nurs 32(4 Suppl): S12-S18.

14. Anonymous (2014) Prussic acid poisoning in livestock. Washington state university extension fact sheet, FS129E, pp. 1-3.

\section{Your next submission with Juniper Publishers} will reach you the below assets

- Quality Editorial service

- Swift Peer Review

- Reprints availability

- E-prints Service

- Manuscript Podcast for convenient understanding

- Global attainment for your research

- Manuscript accessibility in different formats

( Pdf, E-pub, Full Text, Audio)

- Unceasing customer service

Track the below URL for one-step submission

https://juniperpublishers.com/online-submission.php 